\title{
The Interaction of Hageman Factor and Immune Complexes
}

\author{
Charles G. Cochrane, Kirk D. Wuepper, Barbara S. Aiken, \\ Susan D. Revak, and Hans L. Spiegelberg \\ From the Department of Experimental Pathology, Scripps Clinic and Research \\ Foundation, La Jolla, California 92037
}

A в S T R A C T The possible interaction of Hageman factor from human or rabbit plasma with a variety of immunologic reactants was studied. Evidence of an interaction was not obtained and neither binding of radiolabeled Hageman factor to immune aggregates nor depletion of the Hageman factor from the supernate was observed. Cleavage of the labeled Hageman factor molecule into its 30,000 molecular weight-active fragments was not detectable after incubation with immune complexes.

Isolated Hageman factor was far more sensitive to activation than Hageman factor in plasma or serum. There was no consistent activation of isolated Hageman factor by immunologic reactants as determined by conversion of prekallikrein to its enzymatic form or by shortening of the clotting time of factor XII-deficient plasma. A variety of immunologic stimuli were tested: $(a)$ antigen-antibody complexes in soluble or precipitated form; (b) particulate antigen-antibody complexes, i.e., zymosananti-zymosan in which a surface was presented for activation; (c) human IgM-IgG and IgG-IgG (rheumatoid factor) complexes; $(d)$ immune aggregates consisting of heat or bis-diazotized benzidine-aggregated myeloma proteins of all human immunoglobulin classes and subclasses: $\operatorname{IgG}_{1,2,3,4}, \operatorname{IgA}, \operatorname{IgD}, \operatorname{Ig} M$, and $\operatorname{IgE}$. Absorption with immune aggregates did not reduce the quantity of Hageman factor in solution, nor was the Hageman factor bound to the precipitates. The presence of plasma or serum with immune aggregates did not generate activity of the Hageman factor.

The only preparations of immunoglobulins capable of activating Hageman factor were found to be contami-

Dr. Wuepper is the recipient of U. S. Public Health Service Research Career Development Award 1 K4 AM 40, 086-01. Dr. Spiegelberg is supported by grants 70710 from the American Heart Association, Special grant 531 from the American Cancer Society, California Division, and is a Faculty Research Associate of the American Cancer Society (PRA-38).

Received for publication 3 April 1972 and in revised form 13 June 1972. nated with bacteria. These bacteria, upon isolation, activated Hageman factor.

\section{INTRODUCTION}

Little is known about the participation of the kinin-forming and intrinsic clotting systems in inflammatory injury. Components of these systems may be activated by factors inducing inflammation or by plasma and cellular participants brought into the site secondarily. Among the inciting factors capable of inducing inflammatory reactions that have been considered as activators of the kininforming and intrinsic clotting systems are complexes of antigen and antibody.

Various methods have been employed to test for activation of Hageman factor and the kinin-forming system by immune reactants. Immune complexes have been added to fresh plasma to determine if kinin is released or kininogen depleted. Similarly, immune complexes have been added to normal plasma not previously exposed to glass to determine the effect upon the recalcification clotting time of the plasma. Finally, immune precipitates have been exposed to serum that had not contacted glass and the precipitates, after centrifugation, eluted to search for active components of the kinin system.

In order to measure activation of Hageman factor directly, it has been necessary to isolate and purify Hageman factor. In this way, the interaction with immune complexes could be measured directly and the effect upon the Hageman factor molecule assessed. We have recently reported studies describing the purification and characterization of Hageman factor from human and rabbit plasma (1). The molecule has been labeled with ${ }^{125}$ I for studies of its activation (2). When negatively charged particles such as kaolin were added, the ${ }^{125}$ I-labeled Hageman factor became bound to the particles and was activated so as to generate the conversion of prekallikrein to kallikrein and to promote clotting of Hageman-deficient plasma. By contrast, when Hageman factor was exposed to an en- 
zyme such as trypsin, the molecule was cleaved into three equal-sized fragments of 30,000 daltons. These fragments, possessing enzymatic activity (3), were termed prekallikrein activator (PKA). ${ }^{1}$

In accordance with these findings, the activation of purified Hageman factor by immune reactants was assessed by $(a)$ its ability to activate isolated prekallikrein or promote clotting of Hageman-deficient plasma; $(b)$ its binding to immune reactants; and $(c)$ its cleavage into 30,000 molecular weight subunits after interaction with immune reactants.

\section{METHODS}

Preparation of protein reagents. Hageman factor was prepared from human and rabbit plasma by methods recently described in this laboratory (1). The Hageman factor was employed at a concentration of $50-100 \mu \mathrm{g} / \mathrm{ml}$. Briefly, plasma of each species was fractionated with ammonium sulfate. The fraction soluble at $25 \%$ and insoluble at $55 \%$ saturation was then applied to a column of DEAE Sephadex A-50. After elution, the Hageman factor-rich fractions were passed successively over a second column of DEAE Sephadex A-50, G-200 Sephadex and CM Sephadex C-50. At no time did the plasma fractions touch glass. The Hageman factor thus obtained was free from apparent contaminating proteins as judged by electrophoresis in polyacrylamide gels. The Hageman factor did not contain functional activities of other members of the kinin-forming or intrinsic clotting systems (1) and contained undetectable quantities of plasminogen and plasmin. It would not activate prekallikrein or significantly promote clotting of factor XII-deficient plasma without prior activation with either kaolin or trypsin. This indicated the Hageman factor was in precursor form. The purified Hageman factor was labeled with ${ }^{125} \mathrm{I}$ according to published methods (4). After dialysis the ${ }^{125} \mathrm{I}$-labeled Hageman factor was passed over Sephadex G-75 to eliminate traces of free ${ }^{125} \mathrm{I}$. Evidence that the ${ }^{125} \mathrm{I}$ label was bound to Hageman factor was as follows: the labeled protein eluted from G-200 Sephadex with the same volume of elution as unlabeled Hageman factor, sedimented at $4.5 \mathrm{~S}$ in gradients of sucrose and, upon electrophoresis in polyacrylamide gel, migrated in the identical region where Hageman factor activity was detected.

Prekallikrein. Prekallikrein of rabbit plasma was prepared as published previously (5). In general, prekallikrein that was passed over two columns of DEAE Sephadex A-50 was employed. This reagent $(12.5 \mu \mathrm{g} / \mathrm{ml})$ was stable, readily activated, and contained no detectable inhibitor of members of the kinin-forming system. Further purification on CM Sephadex C-50 and by electrophoresis in Pevikon (5) did not change the results.

Immunologic reactants. Rabbit antibodies to human IgG (HGG), bovine IgG (BGG), and bovine albumin (BSA) were obtained after multiple injections of the proteins in saline. The antisera, containing 500-1000 $\mu$ g antibody $\mathrm{N} / \mathrm{ml}$, were fractionated first with ammonium sulfate at $50 \%$ saturation, and then by DEAE-cellulose chromatography

${ }^{1}$ Abbreviations used in this paper: anti-BGG, rabbit antibody to bovine IgG; anti-BSA, rabbit antibody to bovine albumin; anti-HGG, rabbit antibody to human IgG; PKA, prekallikrein activator; TBS, tris-buffered saline; $\mathrm{BAEe}$, benzoyl-l-arginine ethyl ester. to obtain the $\boldsymbol{\gamma}_{2}$-fraction. The quantity of antibody was measured by precipitin reaction. The pools of antibody were divided into portions and kept frozen. This was essential to avoid contamination with bacteria. To prepare immune complexes, antigen was added to the antibody at equivalence. After incubation at $37^{\circ} \mathrm{C} 30 \mathrm{~min}$ and at $4^{\circ} \mathrm{C} 30 \mathrm{~min}$, the resulting precipitate was washed three times with cold 0.01 M Tris(hydroxymethyl) aminomethane $\mathrm{pH} 7.4$ in $0.15 \mathrm{M}$ $\mathrm{NaCl}$ (TBS). It was then resuspended in the same buffer and used for activation of Hageman factor. When tests were performed in an excess of antigen or antibody, or when the immune reactants were brought together in the presence of Hageman factor, the precipitation step was omitted. Zymosan was obtained from ICN Nutritional Biochemicals, Cleveland, Ohio. The zymosan was heated at $100^{\circ} \mathrm{C} 30 \mathrm{~min}$ and then washed. Antibodies were obtained by injecting rabbits with $5 \mathrm{mg}$ zymosan in incomplete Freund's adjuvant at monthly intervals. The resulting antibody was fractionated as noted above for anti-HGG and labeled with ${ }^{125} \mathrm{I}$ to allow quantitative measurements of the amount bound to zymosan.

Aggregation of immunoglobulins and myeloma proteins. Myeloma proteins were isolated from the serum of patients with multiple myeloma either by DEAE-cellulose chromatography or Pevikon block electrophoresis. $\gamma \mathrm{A}$ - and $\gamma \mathrm{D}$-myeloma proteins were further purified by Sephadex G-200 gel filtration. The $\gamma \mathrm{M}$-macroglobulins were isolated by euglobulin precipitation followed by gel filtration on Sephadex G-200' columns. The purified myeloma proteins and normal $\gamma \mathrm{G}$-immunoglobulin were then aggregated by heat at $63^{\circ} \mathrm{C}$ for $20 \mathrm{~min}$ or with bis-diazotized benzidine according to the method of Ishizaka, Ishizaka, Salmon, and Fudenberg (6).

Actization of Hageman factor. Preparations of antibodies and antigens, aggregated myeloma proteins, and kaolin, etc., were added to Hageman factor. The Hageman factor employed was most frequently that in the peak tubes eluting from G-200 Sephadex, i.e., from the fourth step in purification. In the case of human Hageman factor, the concentration of Hageman factor in these tubes was 240 $500 \mu \mathrm{g} / \mathrm{ml}$ as determined by quantitative immune diffusion assay. The Hageman factor was readily activated by $25 \mu \mathrm{g}$ kaolin or 1-2 $\mu \mathrm{g}$ trypsin. Volumes were brought to 0.15 or in some experiments $0.20 \mathrm{ml}$ with TBS. Hageman factor was incubated with immune reactants for $20 \mathrm{~min}$ at either 37 or $22^{\circ} \mathrm{C}$. Prekallikrein, $1.2 \mu \mathrm{g}$ or at times $3.5 \mu \mathrm{g}$ in $0.1 \mathrm{ml}$, was added and the incubation continued at $37^{\circ} \mathrm{C} 20$ min. Following this, $3.0 \mathrm{ml} 1 \mathrm{~mm}$ BAEe was added and the mixture incubated at $37^{\circ} \mathrm{C}$ for $30 \mathrm{~min}$. Hydrolysis of BAEe was then measured by absorption of UV light at $253 \mathrm{~nm}$ (7). The readings were corrected for the amount of absorption at $253 \mathrm{~nm}$ given by the protein present as measured at $280 \mathrm{~nm}$. This was generally $70-90 \%$ of the reading at $280 \mathrm{~nm}$. The tubes were then warmed to $37^{\circ} \mathrm{C}$ for a second incubation of an additional 1 or $2 \mathrm{hr}$. The increase in absorption at $253 \mathrm{~nm}$ between the two periods was used as a measure of the degree of activation. Assays of clot promotion were performed by adding treated or control Hageman factor in 0.1-0.05 ml Hageman-deficient plasma in plastic tubes. After incubation for $6 \mathrm{~min}$ at $37^{\circ} \mathrm{C}$, the tubes were brought to room temperature and $0.05 \mathrm{ml}$ cephalin (Sigma Chemicals, St. Louis, Mo.) and $0.05 \mathrm{ml} \mathrm{CaCl}$, $0.05 \mathrm{M}$ were added to the preparations. The interval in hundredths of minutes between addition of $\mathrm{Ca}^{++}$and the time required for a solid clot to form at room temperature was recorded. 
TABLE I

Inhibition of Absorption of Human Hageman Factor to Kaolin by Plasma*

\begin{tabular}{ccccc}
\hline $\begin{array}{c}\text { Hageman } \\
\text { factor }\end{array}$ & $\begin{array}{c}\text { Hageman- } \\
\text { deficient plasma } \\
\text { (diluted in } \\
0.1 \mathrm{ml})\end{array}$ & Kaolin & $\begin{array}{c}\text { Hageman } \\
\text { factor } \\
\text { remaining } \ddagger\end{array}$ & $\begin{array}{c}\text { Hageman factor } \\
\text { activity on kaolin } \\
\text { (O.D. 253 nm) }\end{array}$ \\
\hline$m l$ & & $\mu g$ & $\%$ & \\
0.1 & Undiluted & 125 & 100 & 0.040 \\
0.1 & $1 / 2$ & 125 & 94 & 0.053 \\
0.1 & $1 / 4$ & 125 & 84 & 0.112 \\
0.1 & $1 / 16$ & 125 & 50 & 0.201 \\
0.1 & - & 125 & 0 & 0.427 \\
0.1 & Undiluted & 125 & - & 0.000 \\
\hline
\end{tabular}

* Isolated Hageman factor was incubated with dilutions of Hageman (XII)-deficient plasma $37^{\circ} \mathrm{C} 10 \mathrm{~min}$. The kaolin was removed by sedimentation and washed before assaying for bound Hageman factor (PKA) capacity.

$\ddagger$ Determined by quantitative immune diffusion assay on the supernate after sedimentation of kaolin.

Chromatography and ultracentrifugation were performed as published previously (1).

Antibody to human Hageman factor was prepared by immunizing rabbits with Hageman factor obtained after four steps of purification, i.e, after fractionation by gel filtration on G-200 Sephadex (1). Antibodies to contaminant proteins were removed by absorption with small quantities of Hageman-deficient plasma. The resulting antibody reacted with normal plasma to yield a single precipitin band in agar diffusion plates. No precipitate occurred with Hageman-deficient plasma from three individuals. The antibody reacted strongly with highly purified human Hageman factor obtained from chromatography on CM Sephadex C-50 (1).

Incubation of immune precipitates with serum or plasma. Assay's of active components of the kinin-forming sy'stem in cluates of the precipitates. Rabbit anti-BGG, anti-HGG, and anti-BSA, 6 or $12 \mathrm{mg}$ antibody protein were mixed with equivalent amounts of antigen in a plastic $40 \mathrm{ml}$ tube, incubated at $37^{\circ} \mathrm{C}, 30 \mathrm{~min}$, cooled to $4^{\circ} \mathrm{C}$ for $30 \mathrm{~min}$, and centrifuged. The precipitates were washed three times in TBS, and mixed thoroughly with $10 \mathrm{ml}$ fresh rabbit serum/ $6 \mathrm{mg}$ antibody, or, in other experiments, guinea pig serum. The sera were obtained using siliconized needles and plastic containers. In two experiments, plasma obtained in acid citrate dextrose anticoagulant was substituted for serum. Incubation of precipitates and serum (or plasma) followed with agitation $10 \mathrm{~min}$ at $37^{\circ} \mathrm{C}$. The precipitate was then removed by sedimentation, and treated with $5 \mathrm{ml}$ of $0.5 \mathrm{M}$ $\mathrm{NaCl}$ in $0.1 \mathrm{M}$ Tris $\mathrm{pH} 8.0$. The elution with $0.5 \mathrm{M} \mathrm{NaCl}$ was repeated twice, the first two eluates combined and dialyzed against an excess of TBS $18 \mathrm{hr}$. The dialyzed eluate was then assayed for its capacity to activate prekallikrein and reduce the clotting time of plasma. Plasma deficient in Hageman factor was generously contributed by Mrs. Gunda Hiatt and plasmas deficient in factors XI and IX by Dr. Samuel Rappaport. The precipitates, after elution, were washed with TBS. Control tubes included $(a)$ immune precipitate with TBS instead of serum or plasma, (b) serum or plasma without immune precipitates (i.e., exposed only to the plastic tube), (c) serum or plasma mixed with $5 \mathrm{mg}$ kaolin, and $(d)$ precipitates exposed to serum that was washed once with $20 \mathrm{ml}$ TBS before elution with $0.5 \mathrm{M} \mathrm{NaCl}$. In some experiments, ${ }^{125}$ I-labeled Hageman factor was added to the serum or plasma to follow the molecule through various procedures.

\section{RESULTS}

Comparison of the capacity of scmipurificd and nonpurified Hagcman factor to be activated. It was essential to determine the comparative sensitivity of activation of Hageman factor in whole plasma and after isolation. Studies of the activation of Hageman factor should be performed on the most readily activated preparation. Accordingly, isolated human Hageman factor was obtained following the first four steps in purification, i.e., after elution from Sephadex G-200 (1). The tube containing the greatest concentration of Hageman factor and the least number of contaminating proteins was selected. The Hageman factor so prepared was then tested for activation alone, or mixed with various concentrations of plasma obtained from an individual genetically deficient in Hageman factor. In order to activate and absorb the Hageman factor, $125 \mu \mathrm{g}$ kaolin was added to each preparation in a constant final volume. After incubation, the kaolin was sedimented, washed, and assayed for prekallikrein-activating (PKA) capacity. The supernate was tested by quantitative immune diffusion for residual Hageman factor protein. The results are shown in Table I. They reveal that increasing concentrations of Hageman-deficient plasma interfere with the capacity of Hageman factor to become bound to and activated by the kaolin. Similar inhibition of binding of ${ }^{125}$ I-labeled Hageman factor to kaolin by normal human plasma was observed in other experiments. The possibility was considered that inhibitors of PKA in plasma could account

TABLE II

Lack of Activation of Isolated Hageman Factor by Immune Precipitate*

\begin{tabular}{cccc}
\hline Anti-HGG & HGG & $\begin{array}{c}\text { Hageman } \\
\text { factor }\end{array}$ & $\begin{array}{c}\text { Prekallikrein } \\
\text { activation } \\
(\text { o.d. 253 nm })\end{array}$ \\
\hline & $\mu g$ & $m l$ & \\
625 & 38 & 0.1 & 0.019 \\
625 & 250 & 0.1 & 0.045 \\
625 & 500 & 0.1 & 0.025 \\
625 & 250 & - & 0.023 \\
625 & $250+$ kaolin & 0.1 & 0.205 \\
& $(25 \mu \mathrm{g})$ & & \\
\hline
\end{tabular}

* Precipitates of human IgG and rabbit antibody exposed to isolated rabbit Hageman factor. After incubation at $22^{\circ} \mathrm{C}$ $15 \mathrm{~min}$, isolated rabbit prekallikrein $(1.25 \mu \mathrm{g})$ added, and incubation continued $30 \mathrm{~min}$ at $37^{\circ} \mathrm{C}$. BAEe $(3 \mathrm{ml})$ then added and hydrolysis measured after $1 \mathrm{hr}$ at $37^{\circ} \mathrm{C}$ at o.D. $253 \mathrm{~nm}$. 
for the decreasing activity of Hageman factor on the kaolin. To test this possibility, kaolin was first exposed to isolated Hageman factor and then washed and mixed with various dilutions of Hageman factor-deficient plasma at $37^{\circ} \mathrm{C} 15 \mathrm{~min}$. Partial $(30 \%)$ inhibition of PKA activity was noted in preparations exposed to undiluted plasma, but considerably less occurred with plasma diluted one-half. It should be noted, however, that complete inhibition of absorption onto kaolin was not observed when larger quantities of kaolin were used (as will be noted in Table V).

In the subsequent studies, isolated Hageman factor was employed that was obtained from Sephadex G-200, i.e., the fourth step of purification. This course was preferable to that of the final step in purification (CM Sephadex C-50) because of greater concentrations of the Hageman factor and because of a lessened tendency to activate spontaneously.

Tests for activation of isolated Hageman factor by immune precipitates. Immune precipitates consisting of rabbit antibodies to BSA, BGG, and HGG and their respective antigens were prepared at equivalence. After washing in TBS they were exposed to rabbit Hageman factor and assays were performed of possible activation. Little or no specific activation of Hageman factor was observed in over 25 such tests using quantities of antibody ranging from 0.03 to $6 \mathrm{mg}$. A typical experiment is shown in Table II.

The possibility was considered that activation might occur if antibody and antigen were combined in the presence of Hageman factor. To test this, anti-HGG $(200 \mu \mathrm{g})$ was added to Hageman factor and the equivalent quantity of antigen added. Again, activation failed to occur. In addition, immune complexes prepared with $625 \mu \mathrm{g}$ antibody and different quantities of antigen, varying from antibody excess through equivalence into antigen excess (fivefold excess of antigen above that needed at equivalence) were also tested for their capacity to activate Hageman factor. In all cases, using anti-BSA or antihuman IgG, activation of Hageman factor did not take place. In each experiment, addition of kaolin to the immune precipitates either during or after incubation with Hageman factor brought about activation of the Hageman factor. Both promotion of clotting and activation of prekallikrein were observed.

When the immune precipitates or heat aggregated $\gamma$-globulin and Hageman factor were incubated and added to factor XII-deficient plasma, specific shortening of the clotting time upon recalcification was not observed. Addition of kaolin to the immune precipitates and Hageman factor induced marked shortening of the clotting time (Table III).

In order to find if fresh serum was important in the activation of Hageman factor, fresh normal rabbit or
TABLE III

The Effect of Aggregated $\gamma$-Globulin and Kaolin on the Clot. Promoting Activity of Human Hageman Factor

\begin{tabular}{ccccc}
\hline Activator* & $\begin{array}{c}\text { Hageman } \\
\text { factor }\end{array}$ & $\begin{array}{c}\text { Clotting } \\
\text { time }\end{array}$ & $\begin{array}{c}\text { BAEe } \\
\text { hydrolysis }\end{array}$ \\
\hline \multirow{2}{*}{ Kaolin } & $\mu g$ & $0.3 \mathrm{ml}$ & $\min$ & \\
& 25 & & & \\
& 50 & + & 5.98 & 0.131 \\
& 100 & + & 4.80 & 0.272 \\
& & + & 2.86 & max
\end{tabular}

Heat aggregated HGG

250

500

1000

$+\quad 8.72$

0.089

$+\quad 9.20$

$+\quad 9.10$

0.088

$+\quad 8.05$

0.102

0.078

* Potential activator was added to purified human Hageman factor and sufficient tris-buffered saline ( $\mathrm{pH} \mathrm{7.5)} \mathrm{to} \mathrm{yield} \mathrm{a}$ total volume of $0.5 \mathrm{ml}$. Incubation was carried out at $22^{\circ} \mathrm{C}$ $20 \mathrm{~min}$. Similar results were obtained with incubation at $37^{\circ} \mathrm{C}$. $\ddagger 0.1 \mathrm{ml}$ incubated mixture added to $0.05 \mathrm{ml}$ cephalin and $0.05 \mathrm{ml}$ factor XII-deficient plasma. After $6 \mathrm{~min}$ at $37^{\circ} \mathrm{C}$ $0.05 \mathrm{ml}, 0.05 \mathrm{M} \mathrm{CaCl}_{2}$ added at room temperature. The clotting time was recorded when a firm clot formed. The average of two times is given.

$\S 0.1 \mathrm{ml}$ incubated mixture added to $0.1 \mathrm{ml}$ prekallikrein $(3.7 \mu \mathrm{g})$ and incubated $37^{\circ} \mathrm{C} 30 \mathrm{~min}$. BAEe then added and the increase in BA generated between 60 and $120 \mathrm{~min}$ recorded. max, maximal hydrolysis at $60 \mathrm{~min}$.

human serum was added to the Hageman factor and immune precipitates. After incubation at $37^{\circ} \mathrm{C} 15 \mathrm{~min}$ and washing of the precipitates, prekallikrein was added as before. Again, there was no activation of the Hageman factor as determined by conversion of prekallikrein. Washing of the precipitates after exposure to serum or plasma was necessary to eliminate inhibitors of kallikrein.

A particulate antigen was also tested. Zymosan (500 $\mu \mathrm{g})$, zymosan with antibody (14.4-20.9 $\mu \mathrm{g}$ antibody/ $500 \mu \mathrm{g}$ zymosan), or zymosan with antibody exposed to fresh rabbit serum (one-fifth dilution) was employed. The particles exposed to serum were washed in TBS before adding Hageman factor. Evidence that the zymosan exposed to antibody and then fresh rabbit serum had bound C 3 was demonstrated by immune adherence of rabbit platelets to these particles. Platelets did not adhere to zymosan, or zymosan with antibody alone. Exposure of each preparation of zymosan to rabbit Hageman factor revealed no specific activation of the Hageman factor. There was no shortening of the clotting time of factor XII-deficient plasma and no conversion of prekallikrein to its active form. Again, 50 $\mu \mathrm{g}$ kaolin incorporated in the mixture, induced activa- 


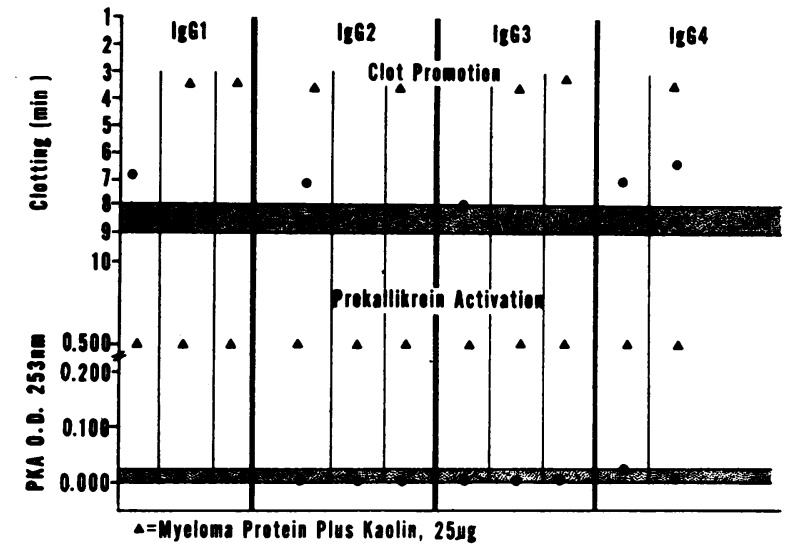

FIgURE 1 Tests for activation of human Hageman factor by aggregated myeloma proteins. The first two columns in each class represent different myeloma proteins aggregated by bis-diazotized benzidine. The third column shows proteins aggregated by heat $\left(63^{\circ} \mathrm{C}, 20 \mathrm{~min}\right) .250 \mu \mathrm{g}$ of aggregated myeloma protein was used. Activation of prekallikrein was measured by the ability of the activated enzyme to cleave BAEe. $25 \mu \mathrm{g}$ kaolin (triangles) was mixed with the aggregated myeloma protein to test possible inhibition of activation by the proteins.

tion of the Hageman factor to the same extent as when the kaolin was added alone to the Hageman factor.

Tests of the activation of Hageman factor with aggregated purified human myeloma proteins. Myeloma proteins, aggregated by either bis-diazotized benzidine or heat, were added to isolated human Hageman factor. The formation of PKA and clot-promoting properties were tested. The results are given in Figs. 1 and 2 . They demonstrate that neither PKA nor clot-promoting activity was generated by aggregates of immunoglobulins $\operatorname{IgG}_{1,2,3,4}, \operatorname{IgA}, \operatorname{IgD}$, and $\operatorname{IgM}$. A single-aggregated $\mathrm{IgE}$ myeloma protein also failed to activate Hageman factor. The results in Figs. 1 and 2 represent duplicate and, in most cases, quadruplicate determinations. Lower doses of aggregated proteins, i.e., $125 \mu \mathrm{g}$, also failed to activate Hageman factor. Each determination shown represents an experiment with a different myeloma protein of that class or subclass. The proteins in the first column were heavily aggregated with bis-diazotized benzidine so that a fine precipitate developed, while those in the second column were lightly aggregated. Ultracentrifugation of the latter proteins in gradients of sucrose revealed the presence of aggregates. In order to find if inhibitors existed in the preparations of myeloma proteins that would prevent detection of activation, kaolin was added in minimal quantity $(25 \mu \mathrm{g})$ to the combination of Hageman factor and each myeloma protein. As noted in Figs. 1 and 2, clotpromoting and PKA activity were readily detected. The clotting times and rate of activation of prekallikrein were the same as those when kaolin was added to the Hageman factor alone.

Some clot-promoting activity was demonstrated with two $\mathrm{IgG}_{4}$ and one of three $\mathrm{IgA}$ proteins when they were added to Hageman factor although no PKA activity was detected with these preparations. All three proteins had a fast $\beta$-electrophoretic mobility and could not be purified free of other $\beta$-globulins. Therefore, tests were performed in order to determine if these proteins promote clot formation in the absence of Hageman factor. The results showed indeed spontaneous clot-promoting activity in both $\mathrm{IgG}_{4}$ and the single positive $\mathrm{IgA}$ protein. It was therefore not possible to attribute clotpromoting activity to activation of Hageman factor.

In order to find if the aggregated myeloma proteins exhibited other biologic activities, the proteins were tested for their ability to utilize complement. $62 \mu \mathrm{g}$ of two different heat-aggregated myeloma proteins of each class and subclass was added to $0.25 \mathrm{ml}$ fresh human serum. After incubation at $4^{\circ} \mathrm{C} 16 \mathrm{hr}$, the residual hemolytic-complement activity was determined. IgGi, $\mathrm{IgG}_{3}$, and $\operatorname{IgM}$ reduced hemolytic levels 28,54 , and $26 \%$, respectively. The other aggregated myeloma proteins failed to reduce hemolytic activity.

Tests for activation of Hageman factor with two different cryoglobulins were performed using 50, 100, 200,500 , and $1000 \mu \mathrm{g}$ of the cryoglobulins. One was an IgM-IgG-mixed cryoglobulin and the other an IgGIgG cryoglobulin. The cryoglobulins were allowed to warm from 0 to $37^{\circ} \mathrm{C}$ in the presence of Hageman factor over a $30 \mathrm{~min}$ period. The proteins were thereby solubilized gradually. The single examples in three experiments shown in Fig. 2 were typical, showing neither generation of PKA nor clot-promoting activities. Two other IgM-IgG-mixed cryoglobulins were

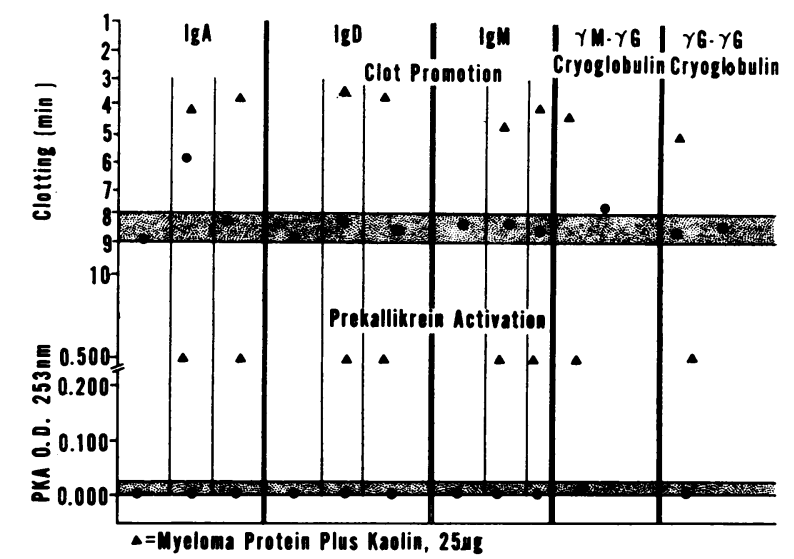

Figure 2 Same as Fig. 1 except IgM-IgG and IgG-IgG cryoglobulins were also tested. $250 \mu \mathrm{g}$ of each protein was assayed. The cryoprecipitate was allowed to warm and dissolve in the presence of Hageman factor at $37^{\circ} \mathrm{C}$. 


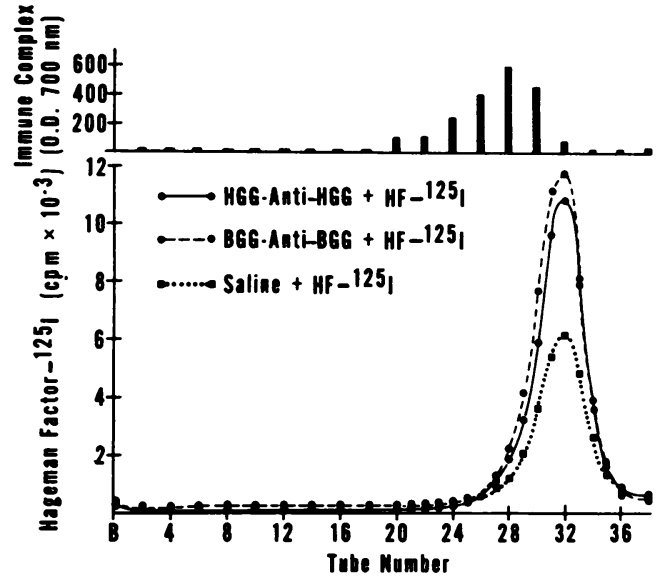

Figure 3 Sedimentation of ${ }^{125}$ I-labeled human Hageman factor with soluble immune complexes of HGG-anti-HGG or BGG-anti-BGG after incubation $15 \mathrm{~min}, 25^{\circ} \mathrm{C}$. The complexes were solubilized from washed precipitates by addition of antigen equal in amount to 10 times that employed at equivalence (see text). Sedimentation in $5-20 \%$ sucrose, $65,000 \mathrm{rpm}, 5 \mathrm{hr}$.

tested in amounts of approximately $150 \mu \mathrm{g}$ with similar results. And finally, an IgM paraprotein, IgM Las, obtained from a patient with Waldenström's macroglobulinemia (kindly donated by Dr. John Johnson, Department of Rheumatology, Scripps Clinic and Research Foundation, La Jolla, Calif.) (8) shown to bind but not to precipitate IgG, was tested for its ability to activate Hageman factor. 250 and $500 \mu \mathrm{g}$ in $0.1 \mathrm{ml}$ combined with 50 and $200 \mu \mathrm{g}$ respectively of heataggregated human IgG failed to activate either clotpromoting or PKA activity. In contrast, when $50 \mu \mathrm{g}$ kaolin was added to the mixture of three proteins in a separate tube as a control, the Hageman factor was activated. The results with $\operatorname{IgM}_{\text {Lay }}$ were similar to those presented in Fig. 2.

On three occasions during the course of these studies, aggregated immunoglobulin preparations were found that activated Hageman factor. These preparations had been held at $4^{\circ} \mathrm{C}$ for 3 wk to several months before use, and were found upon culture to contain Pseudomonas alcaligenes in two preparations and Escherichia coli in the other. When cultures of the bacteria were tested by themselves, they were found to be potent activators of Hageman factor.

Tests of binding of radiolabeled Hageman factor to soluble immune complexes. Hageman factor from rabbit and human plasma was labeled with ${ }^{125} \mathrm{I}$ and tested for its ability to bind to immune complexes, both soluble and insoluble. Soluble complexes of rabbit antibodies to human IgG and bovine IgG containing $250 \mu \mathrm{g}$ antibody were prepared and incubated with ${ }^{125}$ I-labeled Hageman factor. Similarly, isolated rheumatoid factor (latex agglutination titer of 512 ) was mixed at $37^{\circ} \mathrm{C}$ with ${ }^{125} \mathrm{I}-$ labeled human Hageman factor and $100 \mu \mathrm{g}$ heat-aggregated human IgG. After $15 \mathrm{~min}$ incubation, the mixture was ultracentrifuged in a gradient of sucrose (5$20 \%$ ). Typical patterns of centrifugation are shown in Figs. 3 and 4. As noted, the immune complexes or rheumatoid factor-aggregated IgG complexes sedimented more rapidly than the ${ }^{125}$ I-labeled Hageman factor. The pattern of Hageman factor in the presence of immune complexes was indistinguishable from that in the absence of immune complexes. In addition, no evidence of breakdown of Hageman factor into its 2.6S subunits was observed. The addition of fresh rabbit plasma or human serum to the incubation mixture (diluted one-fifth in the protein solutions) did not alter the pattern of sedimentation of the Hageman factor. It should be emphasized that the ${ }^{125} \mathrm{I}$-labeled Hageman factor was fully capable of binding to and being activated by kaolin. When tested before sedimentation, the Hageman factor was found not to be activated by the immune complexes.

Attempts to elute active products of Hageman factor from immune precipitates exposed to normal plasma or serum. Precipitates of rabbit anti-BSA, BGG, and HGG were prepared with equivalent amounts of antigen, exposed to fresh serum or plasma, and eluted with $0.5 \mathrm{M} \mathrm{NaCl}$ as described in Methods. The eluates were dialyzed and tested in various quantities for their ability to activate prekallikrein and promote clotting of plasma. Five experiments were performed, yielding similar data.

The results of one such experiment are shown in Table IV. As noted, active Hageman factor did not appear in the eluate as tested by prekallikrein activation, while eluates of kaolin treated with normal serum

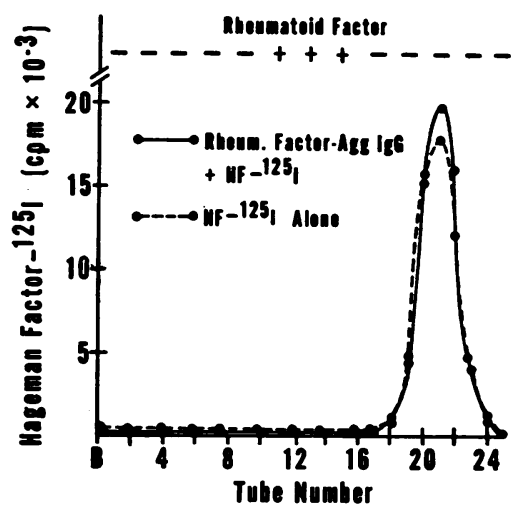

FIgURE 4 Sedimentation of rheumatoid factor-aggregated human $\operatorname{IgG}$ with ${ }^{125}$ I-labeled human Hageman factor after incubation. Conditions of incubation and sedimentation were the same as those in Fig. 3. 
TABLE IV

Lack of Actication of Hageman Factor in Normal Serum by Immune Precipitates

\begin{tabular}{|c|c|c|c|}
\hline \multicolumn{4}{|c|}{ Conversion of prekallikrein to kallikrein } \\
\hline Eluate* & Prekallikrein & \multicolumn{2}{|c|}{$\begin{array}{l}\text { Hydrolysis of BAEe } \\
\quad(\text { o.D. } 253 \mathrm{~nm}) \ddagger\end{array}$} \\
\hline \multicolumn{4}{|c|}{$\stackrel{m l}{\mu g}{ }_{\text {Eluate of normal rabbit serum }}+$ immune precipitate } \\
\hline 0.25 & 1.25 & \multicolumn{2}{|c|}{0.036} \\
\hline 0.50 & 1.25 & \multicolumn{2}{|c|}{0.008} \\
\hline 0.50 & 一 & \multicolumn{2}{|c|}{$0.05 t$} \\
\hline \multicolumn{4}{|c|}{ Eluate of TBS + immune precipitate } \\
\hline 0.25 & 1.25 & \multicolumn{2}{|c|}{0.032} \\
\hline 0.50 & 1.25 & \multicolumn{2}{|c|}{0.002} \\
\hline 0.50 & - & \multicolumn{2}{|c|}{0.052} \\
\hline \multicolumn{4}{|c|}{$\begin{array}{l}\text { Eluate of normal rabbit serum }+ \text { immune precipitate after } \\
\text { washing }\end{array}$} \\
\hline 0.25 & 1.25 & \multicolumn{2}{|c|}{0.064} \\
\hline 0.50 & 1.25 & \multicolumn{2}{|c|}{0.092} \\
\hline 0.50 & - & \multicolumn{2}{|c|}{0.096} \\
\hline \multicolumn{4}{|c|}{ Eluate of normal rabbit serum + kaolin } \\
\hline 0.25 & 1.25 & \multicolumn{2}{|c|}{0.208} \\
\hline 0.25 & - & \multicolumn{2}{|c|}{0.042} \\
\hline \multicolumn{4}{|c|}{ Promotion of clotting in plasma } \\
\hline & \multicolumn{3}{|c|}{ Clotting time $(\mathrm{min}) \S$} \\
\hline Eluate of & $\begin{array}{l}\text { XII-deficient } \\
\text { plasma }\end{array}$ & $\begin{array}{l}\text { XI-deficient } \\
\text { plasma }\end{array}$ & $\begin{array}{l}\text { IX-deficient } \\
\text { plasma }\end{array}$ \\
\hline $\begin{array}{l}\text { NRS + immune } \\
\text { precipitate }\end{array}$ & 16.3 & 3.13 & 7.6 \\
\hline $\begin{array}{l}\text { TBS }+ \text { immune } \\
\text { precipitate }\end{array}$ & 26.6 & 5.24 & 27 \\
\hline $\begin{array}{l}\text { NRS + immune } \\
\text { precipitate }\end{array}$ & & & \\
\hline$+\operatorname{wash}(\times 1)$ & 30.7 & 4.22 & 25 \\
\hline - & $>35$ & 6.36 & $>25$ \\
\hline
\end{tabular}

* Normal rabbit serum $(10 \mathrm{ml})$ incubated with BGG-antiBGG precipitate or kaolin. Centrifuged precipitate then eluted with $0.5 \mathrm{M} \mathrm{NaCl}$ in tris buffer, $\mathrm{pH}$ 8.0. Eluate dialyzed against TBS before use.

† Prekallikrein incubated $1 \mathrm{hr}$ with BAEe. No significant difference in results noted after 2 additional hr incubation.

$\S$ See Methods.

exhibited active Hageman factor. Although there was clot-promoting activity in the dialyzed eluates of unwashed precipitates, this was not eluted from the precipitates if they were washed once in TBS before elution with $0.5 \mathrm{M} \mathrm{NaCl}$. In addition, the clot-promoting material shortened the clotting times of not only factor XII-deficient plasma, but factor XI- and IX-deficient plasmas as well.
Human or rabbit Hageman factor labeled with ${ }^{125} \mathrm{I}$ was not bound by the immune precipitates exposed to each respective serum ( $\mathrm{Table} \mathrm{V}$ ) while up to $10 \%$ of the ${ }^{125}$ I-labeled Hageman factor bound to kaolin under identical conditions. There are several factors of note in the experiment summarized in Table V. (a) The amount of Hageman factor in the washed precipitate was considerably reduced after a second wash, there being less than $0.5 \%$ of the total Hageman factor then remaining. The amount bound to kaolin was not reduced more than $1 \%$ of the total by the second wash. (b) After initial sedimentation and careful decanting of the supernatant serum, $12-15 \%$ of the ${ }^{12}$ I-labeled Hageman factor was left in the plastic tube containing the precipitate. Over half of this was bound to the tube, for when the precipitates were washed and decanted into a fresh plastic tube, $6-8 \%$ of the original Hageman factor was still detected in the tube. The residual Hageman factor resisted removal by washing in buffered saline, but was not active in that it failed to convert prekallikrein to kallikrein (although it would after treatment with typsin). (c) The immune precipitates, with 2-3c\% of the Hageman factor remaining, as shown in Table $\mathrm{V}$, did not activate prekallikrein. $(d)$ This experiment was also performed at 25 and $4^{\circ} \mathrm{C}$. Less Hageman factor was bound to kaolin at $4^{\circ} \mathrm{C}$, but what did bind was inhibited less by the serum than that at 25 or $37^{\circ} \mathrm{C}$. Maximal binding occurred at $25-37^{\circ} \mathrm{C}$ with less inhibition of the active Hageman factor being observed at $25^{\circ} \mathrm{C}$. The amount of Hageman factor in the immune precipitates was constant at each temperature. (e) As noted in Table I, the presence of plasma proteins inhibits uptake of Hageman factor by activator. This finding was confirmed in the studies recorded in Table $\mathrm{V}$ in which significantly more Hageman factor was bound to kaolin when the serum was diluted. As noted, this was reflected in greater loss of Hageman factor from the serum as determined by quantitative immune assay. To test if the ${ }^{125}$ I-labeled Hageman factor in the supernatant serum consisted at least in part of the 30,000 mol. wt. cleavage product, i.e., PKA, the supernatant serum was subjected to ultracentrifugation in a gradient of sucrose. The ${ }^{125} \mathrm{I}$ activity sedimented in a sharp peak at $4.5 \mathrm{~S}$, i.e., in the same position as native Hageman factor. This indicated that Hageman factor had not been cleaved by incubation with immune precipitates.

\section{DISCUSSION}

The experiments presented offer no evidence that Hageman factor interacts with immune complexes and fail to support the possibility that immune aggregates are capable of activating Hageman factor: $(a)$ radiolabeled Hageman factor was not bound by immune aggregates 
while it was by a known activator, kaolin; (b) Hageman factor was not cleaved into its 30,000 mol. wt. subunits, the prekallikrein activators as occurs upon activation with enzymes; $(c)$ complexes of antigen and antibody either in precipitate or soluble form failed to activate isolated Hageman factor so that it would activate prekallikrein or promote clotting of factor XIIdeficient plasma; $(d)$ a particulate antigen. zymosan, together with antibody, failed to induce activation; $(e)$ aggregated human myeloma proteins of all known classes and subclasses failed to activate Hageman factor. This eliminated the possibility that a single class or subclass of immunoglobulin could be effective that may have been deficient in the antibodies used for testing. To test whether the physical form of the aggregate was important in activating Hageman factor, the immunoglobulins were aggregated by both heat $\left(63^{\circ} \mathrm{C}\right.$ for $20 \mathrm{~min}$ ) and bis-diazotized benzidine so as to obtain small and large (visible) aggregates. No effect was noted with each type of aggregated immunoglobulin.

The addition of plasma or serum to immune aggregates did not lead to activation of Hageman factor. In fact, serum or plasma inhibited the uptake of Hageman factor into a known activator, kaolin (Table I), and in separate studies was found to block PKA activity when the Hageman factor was activated by kaolin. Immune precipitates or soluble complexes did not bind Hageman factor in the presence of serum. Zymosan, used as antigen in order to provide a surface for activation, also did not activate Hageman factor when combined with antibody and fresh normal serum. In addition, serum after absorption with immune precipitates did not shown a diminution of Hageman factor.

These studies were facilitated by the availability of ${ }^{125}$ I-labeled human and rabbit Hageman factor and by antibodies directed to the former. These reagents allowed quantitative measurements to be performed on the amount of Hageman factor participating in reactions whether or not it was activated. This is especially important in the present studies in which activation by immune complexes was not observed. All of the Hageman factor could be accounted for at the end of the reaction, which substantiated considerably the results. In addition, it was determined at the outset of these experiments that Hageman factor was far more readily activated after partial purification. Thus, the ability to detect activation was particularly sensitive.

The present studies are in keeping with those of Ratnoff (9) and Robbins and Stetson (10) in which immune complexes failed to promote clotting of plateletpoor plasma. By contrast, several studies have been reported with results that differ from these.

Davies, Lowe, and Holman (11-13) and Movat, DiLorenzo, and Treloar (14-16) have reported that when
TABLE V

Inability of Immune Precipitates to Bind Hageman Factor in Normal Human Serum*

\begin{tabular}{|c|c|c|c|}
\hline $\begin{array}{l}\text { Binding of } \mathrm{HF} \text { to } \\
\mathrm{Ag} \text {-Ab precipitate } \\
\text { or kaolin }\end{array}$ & $\begin{array}{c}\text { NHS } \\
\text { (dilution) }\end{array}$ & $\begin{array}{l}\text { HF remaining } \\
\text { in supernate } \\
\text { (\% of total }) \ddagger\end{array}$ & $\begin{array}{l}\text { HF activity on } \\
\text { Ag-Ab precipitate } \\
\text { or kaolin } \\
\text { (o.D. } 253 \mathrm{~nm} \text { ) }\end{array}$ \\
\hline$\%$ & & & \\
\hline \multicolumn{4}{|c|}{ Ag-Ab precipitate } \\
\hline$\quad 2.9$ & undiluted & & 0.000 \\
\hline 2.8 & $1 / 2$ & 99 & 0.000 \\
\hline \multicolumn{4}{|l|}{ Kaolin } \\
\hline 6.1 & undiluted & & 0.030 \\
\hline 10.0 & $1 / 2$ & 91 & 0.113 \\
\hline
\end{tabular}

* Normal human serum (NHS) containing ${ }^{125}$ I-labeled Hageman factor was mixed with BSA-anti-BSA precipitate $(500 \mu \mathrm{g} \mathrm{Ab})$ or kaolin $(500 \mu \mathrm{g}) 37^{\circ} \mathrm{C} 15 \mathrm{~min}$. The precipitates or kaolin were washed once and then transferred to fresh plastic tubes for counting ${ }^{125} \mathrm{I}$. The results recorded are typical of three separate experiments.

$\ddagger$ Measured by quantitative immune diffusion assay. NHS without addition of $\mathrm{Ag}-\mathrm{Ab}$ precipitate control (100\%).

serum was incubated with immune precipitates, substances were generated that increased vascular permeability. Sera of guinea pig, rabbit, and man were employed although serum of man generated little or no activity (15). Similar conclusions were reached in experiments of Eisen and Smith (17). The data raised the possibility that the kinin system in serum was activated by the immune precipitates. Supporting this interpretation were the findings that the permeability occurred in guinea pigs treated with the antihistaminic mepyraminic maleate $(5 \mathrm{mg} / \mathrm{kg})$, the activity was enhanced if the serum was pretreated with inhibitors of serum carboxypeptidase known to possess kininase activity, generation of the permeability factor was inhibited by various agents known to block formation of kinin, and serum deficient in Hageman factor was inactive. Contrary to this interpretation, however, was the finding that EDTA $\left(5 \times 10^{-2} \mathrm{M}\right)$ inhibited generation of the permeability factor (15). The activation of Hageman factor and the kinin system is unaffected by the presence of EDTA at this concentration.

While several alternative hypotheses might be considered, one that these workers have taken pains to eliminate must still be kept in mind; namely, that the majority of permeability results from the generation of anaphylatoxin through activation of the complement system. Several observations support this conclusion: (a) Inhibitors of the complement system prevented activation of the permeability factor: chelation of the serum with EDTA, heating or addition of salicylaldoxime to the serum before addition of immune precipi- 
tates. It was difficult to generate the permeability factor from citrated plasma. (b) Permeability was enhanced by treating the serum with agents that block serum carboxypeptidase. This would prevent degradation of anaphylatoxin as well as kinins and would therefore protect both activities. Indeed, it is known that anaphylatoxin cannot be measured in human serum after incubation with immune precipitates which conforms to the observation of the authors that generation of permeability factor was not observed in human serum. (c) Adequacy of treatment of the test animals with mepyramine maleate was assessed by intradermal injections of histamine $(1 \mu \mathrm{g})$ rather than by quantities of anaphylatoxin shown to yield reactions of permeability equal to those in the tests. It is known that histamine released endogenously is more difficult to suppress with antihistaminics than histamine administered exogenously.

Further analysis of the serum after treatment with immune precipitates allowed separation of several permeability factors by differing physical properties (18). In addition, elution of unwashed precipitates followed by chromatographic analysis allowed identification of several factors capable of activating members of the kinin system $(18,19)$. However, it is quite possible that activation of the eluates obtained from immune precipitates resulted from the process of dialysis and chromatography. In fact, this has been shown to occur when proper precautions are not taken $(3,5,20)$. In the present studies, abundant Hageman factor, i.e. about $12-15 \%$ of that added in normal serum, remained in the plastic tubes after serum was decanted from the immune precipitates. One-half of this was bound to the tube and essentially all of the remainder could be washed from the precipitate with physiologic saline. The Hageman factor bound to the plastic tube and that removed from precipitate by washing was inactive. Thus elution of the serum treated, unwashed immune precipitate with high concentrations of $\mathrm{NaCl}$ (18) would yield abundant Hageman factor that could be activated during further treatment.

Kaplan, Spragg, Austen, and Gigli $(21,22)$ have reported that IgM Lay, obtained from a patient with Waldenströms macroglobulinemia, when reacted with IgG, activated isolated Hageman factor. In the studies reported here, several IgM proteins having rheumatoid factor activity including IgM Lay, failed to convert isolated Hageman factor to its active form. When small amounts of kaolin were added with these reactants, normal activation was observed indicating that inhibitors of the activation were not present in the IgM or IgG proteins.

Epstein, Tan, and Melmon (23) have presented wellcontrolled studies showing that immunoglobulins with rheumatoid factor activity reacted with IgG to release kinin from plasma that contracted rat uterus and depleted levels of kininogen. The amount of kinin released paralleled the titer of rheumatoid factor. It should be noted that these investigators employed chelated plasma which did not support generation of the vascular permeability factor studied by Movat and DiLorenzo (15). The two factors are therefore probably different. Hageman-deficient plasma failed to support generation of the kinin. In the present studies, isolated Hageman factor was neither bound to nor activated by rheumatoid factor-aggregated IgG complexes. Addition of serum or plasma had no effect on the results. In addition, rheumatoid factor of high titer $(1,000-10,000$ reciprocal dilution ), ${ }^{2}$ isolated chromatographically, was combined with heat-aggregated IgG. This was then added to plasma pretreated with 1-10-orthophenanthroline under conditions identical with those of Epstein et al. (23). Nevertheless, with seven different preparations of rheumatoid factor we failed to obtain either specific kinin release or kininogen depletion. Addition of $200 \mu \mathrm{g}$ kao$\mathrm{lin} / \mathrm{ml}$ plasma in the presence of each rheumatoid factor and heat-aggregated IgG generated kinin and depleted kininogen levels up to $40 \%$. The reason for this discrepancy is not apparent.

Actication by bacteria. In the only instances in which aggregated immunoglobulins, immune complexes, or isolated rheumatoid factors were capable of generating activity from the precursor Hageman factor, bacterial contamination was found in the preparation of immunoglobulin. The bacteria, upon culture and isolation, were capable of activating the Hageman factor. In two cases, Pseudomonas alcaligenes and in a third, E. coli were identified. This finding may illustrate a mechanism of activation of the kinin-forming and intrinsic clotting systems of considerable importance in the host's defense against invading organisms. In addition, it represents a pitfall to investigations of the activation of the kinin-forming system than can mislead proper interpretation.

\section{ACKNOWLEDGMENTS}

This study is publication No. 580 from the Department of Experimental Pathology, Scripps Clinic and Research Foundation, La Jolla, Calif.

The work was supported by U. S. Public Health Service Grant A1-07007, the National Multiple Sclerosis Society Grant 459, the Council for Tobacco Research, U. S. A., and the American Heart Association.

\section{REFERENCES}

1. Cochrane, C. G., and K. D. Wuepper. 1971. The first component of the kinin-forming system in human and rabbit plasma. It relationship to clotting factor XII (Hageman Factor). J. Exp. Med. 134: 986.

\footnotetext{
${ }^{2}$ Generously contributed by Dr. Nathan Zvaifler.
} 
2. Cochrane, C. G., S. S. Sitzer, and B. S. Aikin. 1972. Hageman Factor: its structure and activation. Fed. Proc. 31: 623.

3. Wuepper, K. D., E. S. Tucker III, and C. G. Cochrane. 1970. Plasma kinin system: proenzyme components. J. Immunol. 105 : 1307.

4. McConahey, P. J., and F. J. Dixon. 1966. A method of trace iodination of proteins for immunologic studies. Int. Arch. Allergy Appl. Immunol. 29: 185.

5. Wuepper, K. D., and C. G. Cochrane. 1972. Plasma prokallikrein: isolation, characterization, and mechanism of activation. J. Exp. Med. 135: 1 .

6. Ishizaka, T., K. Ishizaka, S. Salmon, and H. Fudenberg. 1967. Biologic activities of aggregated $\gamma$-globulin. VIII. Aggregated immunoglobulins of different classes. J. Immunol. 99 : 82.

7. Schwert, G. W., and Y. Takenaka. 1955. A spectrophotometric determination of trypsin and chymotrypsin. Biochim. Biophy's. Acta. 16: 570.

8. Stone, M. J., and H. Metzger. 1968. The specificity of a monoclonal macroglobulin $(\gamma \mathrm{M})$ antibody: reactivity with primate $\gamma \mathrm{G}$ immunoglobulins. J. Immunol. 102: 222.

9. Ratnoff, O. D. 1969. Some relationships among hemostasis, fibrinolytic phenomena, immunity, and the inflammatory response. Adv. Immunol. 10: 188.

10. Robbins, J., and C. A. Stetson, Jr. 1959. An effect of antigen-antibody interaction on blood coagulation. $J$. Exp. Med. 109: 1 .

11. Davies, G. E., and J. S. Lowe. 1960. A permeability factor released from guinea-pig serum by antigen-antibody precipitates. Br. J. Exp. Pathol. 41: 335 .

12. Davies, G. E., and J. S. Lowe. 1962. Further studies on a permeability factor released from guinea-pig serum by antigen-antibody precipitates: relationship to serum complement. Int. Arch. Allergy Appl. Immunol. 20: 235.

13. Davies, G. E., G. Holman, and J. S. Lowe. 1967. Role of Hageman factor in the activation of guinea-pig prekallikrein. Br. J. Pharmacol. 29: 55.

14. Movat, H. Z. 1967. Activation of the kinin system by antigen-antibody complexes. In International symposium on Vaso-active Polypeptides: Bradykinin and Related Kinins. M. Rocha e Silva and H. A. Rothschild, editors. Edart Livraria Editora, Ltda., Sâo Paulo, Brazil. 177.

15. Movat, H. Z., and N. L. DiLorenzo. 1968. Activation of the plasma kinin system by antigen-antibody aggregates. I. Generation of permeability factor in guinea pig serum. Lab. Invest. 19: 187.

16. Movat, H. Z., N. L. DiLorenzo, and M. P. Treloar. 1968. Activation of the plasma kinin system by antigenantibody aggregates. II. Isolation of permeability-enhancing and kinin-releasing fractions from activated guinea pig serum. Lab. Invest. 19: 201.

17. Eisen, V., and H. G. Smith. 1970. Plasma kinin formation by complexes of aggregated $\boldsymbol{\gamma}$-globulin and serum proteins. Br. J. Exp. Pathol. 51: 328.

18. Movat, H. Z., M. P. Treloar, and Y. Takeuchi. 1969. A small molecular weight permeability factor in guinea pig serum: adsorption to antigen-antibody aggregates. J. Immunol. $103: 875$.

19. Treloar, M. P., and H. Z. Movat. 1970. Isolation of two small molecular weight activators of plasma kininsystem in the guinea pig. Fed. Proc. $29: 576 \mathrm{a}$.

20. Wuepper, K. D., and C. G. Cochrane. 1972. Isolation and mechanism of activation of components of the plasma kinin-forming system. In Biochemistry of the Acute Allergic Reaction. K. F. Austen and E. L. Becker, editors. Blackwell Scientific Publications Ltd., Oxford. In press.

21. Kaplan, A. P., J. Spragg, and K. F. Austen. 1972. The immunologic activation of the bradykinin-forming system in man. In Biochemistry of the Acute Allergic Response. K. F. Austen and E. L. Becker, editors. Blackwell Scientific Publications Ltd., Oxford. In press.

22. Kaplan, A. P., I. Gigli, and K. F. Austen. 1971. Immunologic activation of Hageman factor and its relationship to fibrinolysis, bradykinin generation and complement. J. Clin. Invest. 50: 51a. (Abstr.)

23. Epstein, W. V., M. Tan, and K. L. Melmon. 1969. Rheumatoid factor and kinin generation. Ann. N. Y. Acad. Sci. 168: 173 . 